\title{
KRITIK SEJARAH BATIK SIDOARJO
}

\author{
Asy Syams Elya Ahmad \\ Program Studi Seni Rupa Murni Jurusan Seni Rupa Fakultas Bahasa dan Seni \\ Universitas Negeri Surabaya \\ Jl. Lidah Wetan, Kecamatan Lakarsantri, Kota Surabaya, Kode Pos 60213 \\ Jawa Timur, Indonesia \\ Email: asyahmad@unesa.ac.id
}

\begin{abstract}
Abstrak
Narasi sejarah batik Sidoarjo yang populer perlu dikaji ulang dengan didasari metodologi sejarah sehingga tidak terjadi bias sejarah yang hanya berdasar pada cerita lisan masyarakat umum. Banyak penelitian yang terjebak dalam pemahaman historisitas setempat yang kurang tepat. Akibatnya, berbagai kajian tersebut tidak berhasil mendudukkan batik Sidoarjo sesuai dengan konteksnya secara utuh, malah menjadi semacam standardisasi narasi pada karakteristik maupun sejarahnya. Penelitian ini bertujuan untuk mengkritisi konstruksi sejarah yang telah populer terkait pemahaman dasar tentang batik Sidoarjo serta menjelaskan kedudukan batik Sidoarjo dalam kerangka budaya masyarakatnya. Artikel ini merupakan upaya penulis untuk memberikan analisis atau paparan yang berbeda dari narasi sejarah batik Sidoarjo yang umum dilakukan pada berbagai pembahasan. Penelitian ini tergolong dalam penelitian kualitatif, dengan menggunakan metode sejarah yang terdiri atas empat tahap, yaitu heuristik, kritik sumber, interpretasi, dan historiografi. Penelitian ini menggunakan pendekatan historis dan sosiologis untuk mengumpulkan, menyeleksi, dan menguji secara kritis sumber-sumber sejarah batik Sidoarjo, sehingga menghasilkan fakta sejarah. Hasil penelitian memperlihatkan bahwa historisitas batik Sidoarjo merujuk pada aktivitas pembatikan yang ada di wilayah Kedungcangkring, Jetis, Sekardangan, Jl. Gajah Mada (China Peranakan), dan Tulangan yang kesemuanya saling terkait memiliki hubungan langsung baik itu pembatikan China peranakan maupun pribumi. Batik Sidoarjo tidak dikerangkai oleh ritual adat, juga tidak di bawah kendali dan dominasi aristokrasi kraton. Pertumbuhannya didasari faktor kebutuhan ekonomi masyarakat pendukungnya, sifatnya cenderung merupakan komoditas dagang. Hadirnya golongan masyarakat atau bangsa lain seperti China Peranakan, Indo-Eropa, Belanda, Arab turut berpengaruh melahirkan batik Sidoarjo.
\end{abstract}

Kata Kunci: batik, Sidoarjo, kritik sejarah

\section{Abstract}

The popular historical narrative of the batik Sidoarjo needs to be reexamined based on historical methodology so that there is no historical bias based only on oral stories of the general public. Many studies are trapped in an inaccurate understanding of local historicity. As a result, these various studies have failed to fit batik Sidoarjo into its full context, instead it has become a kind of narrative standardization on its characteristics and history. This study aims to criticize the historical construction that has been popular in relation to the basic understanding of batik Sidoarjo and to explain the position of batik Sidoarjo in the cultural framework of its people. This article is the author's attempt to provide an analysis or explanation that is different from the historical narrative of batik Sidoarjo which is commonly used in various discussions. This research is classified as a qualitative research, using the historical method which consists of four stages, namely heuristics, source criticism, interpretation, and historiography. This research uses historical and sociological approaches to collect, select, and critically examine historical sources of Sidoarjo batik, resulting in historical facts. The results showed that the historicity of batik Sidoarjo refers to the batik activities in the areas of Kedungcangkring, Jetis, Sekardangan, Gajah Mada St. (Peranakans), and Tulangan, all of which have a direct relationship with both Peranakans nor indigenous. Batik Sidoarjo is not framed by traditional rituals, nor is it under the control and domination of the royal aristocracy. Its growth is based on the factor of the economic needs of the supporting community, which tends to be a trading commodity. The presence of other groups of people or nations such as Peranakan Chinese, Indo-European, Dutch, Arabic contributed to the birth of Sidoarjo batik. .

Keywords: batik, Sidoarjo, historical criticism. 


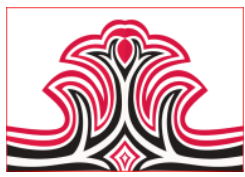

\section{PENDAHULUAN}

Ishwara et al. (2011) menyatakan tidak diketahui dengan pasti kapan batik mulai dibuat di Jawa. Walaupun metode membatik (teknik perintang warna) ditemukan pula di beberapa pulau lain di Nusantara, namun di pulau Jawa-lah metode pembatikan berkembang paling subur. Metode batik tulis yang dibuat dengan canting dan malam, menurut Maxwell (2003) mungkin baru berkembang pada awal abad XVII. Sebelum canting ditemukan, pembubuhan perintang warna dilakukan dengan alat lain seperti misalnya tangkai bambu.

Batik di Jawa Timur dalam berbagai literatur perbatikan tidak begitu terekspos sebagaimana wilayah Jawa Tengah dan Jawa Barat. Pembahasan batik Jawa Timur masih sangat parsial baik itu secara historis maupun keragaman artifaknya. Batik di Jawa Timur tidak tumbuh dalam bingkai kebudayaan keraton namun bisa dikategorikan sebagai perbatikan pesisir, sehingga melahirkan karakter khas di setiap daerahnya dan ekspresinya sangat jauh berbeda dibandingkan dengan batik Jawa pada umumnya.

Carey (1996) mengungkapan pesisir utara Jawa merupakan tempat pertemuan pedagang, pelawat, maupun agamawan dari India, Cina, dan berbagai penjuru Asia Timur. Daerah pesisir terletak jauh dari keraton, penduduknya lebih terpapar dan lebih mudah menyerap pengaruh luar. Heringa \& Veldhuisen (1996) menegaskan bahwa berkembangnya batik pesisir bukan setelah batik keraton Solo-Yogya. Heringa (2010) memperkirakan batik pesisir sudah mulai berkembang sejak abad ke-15.

Beberapa daerah di Jawa Timur saat masa kolonial tercatat menjadi sentra industri perbatikan besar seperti di Sidoarjo, Gresik, Tulungagung, Trenggalek, dan Madura. Batik di Jawa Timur telah lama eksis menjadi bagian dalam kebudayaan masyarakatnya sejak sebelum masa Kesultanan Mataram Islam. Anshori \& Kusrianto (2011) meyakini bahwa batik lebih dahulu muncul di wilayah Jawa Timur juga diperkuat catatan Rouffaer \& Juynboll (1914) yang menyatakan bahwa teknik membatik telah diperkenalkan di Jawa sekitar abad ke-6 atau ke-7 dari pedagang India atau Sri Lanka. Begitu pula Elliott (2004) juga menulis hal yang sama, hanya perkiraan abadnya yang sedikit berbeda.

Sejarah sebagai tulisan tentang masa lampau, yang mengkaji kehidupan manusia yang semuanya mempunyai temporalitas dan historisitas. Kategorikategori pokok dalam pendekatan sejarah meliputi tiga hal yaitu kebinekaan (diversity), perubahan (change),
Gorga : Jurnal Seni Rupa

Volume 10 Nomor 01 Januari-Juni 2021

p-ISSN: 2301-5942 | e-ISSN: 2580-2380

dan kesinambungan (continuity), ketiga hal tersebut melalui dimensi waktu (Irwanto \& Sair, 2014). Kartodirdjo (1993) menegaskan bahwa sejarah dalam arti subjektif merupakan suatu konstruk, yaitu bangunan yang disusun oleh penulis sebagai uraian atau cerita. Uraian atau cerita itu merupakan suatu kesatuan atau unit yang mencakup fakta-fakta terangkaikan untuk menggambarkan gejala sejarah, baik proses maupun struktur.

Keberlangsungan batik hingga masa sekarang adalah akibat dari pergolakan yang senantiasa terjadi pada berbagai aspek, mulai dari aspek teknis, estetis, normatif, ikonografis, simbolis, fungsional dan sebagainya (Anas et al, 1997). Berbagai aspek tersebut berkaitan erat dengan kehidupan sosial budaya masyarakat pendukungnya. Dialektika dalam kain batik mengungkapkan hasrat serta upaya untuk senantiasa tanggap terhadap perubahan. Gustami (2007) mengatakan bahwa perubahan dan perkembangan itu didorong oleh pengaruh internal dan eksternal. Pengaruh internal yakni kondisi pribadi, lingkungan alam sekitar, dan masyarakat setempat. Sedangkan pengaruh eksternal meliputi akibat-akibat terjalinnya hubungan antar daerah, antar bangsa, dan lingkungan masyarakat luas.

Tradisi batik di Indonesia tidak statik melainkan dinamik. Batik dibangun dengan pandangan dasar artistik yang berkembang sesuai dengan tuntutan zaman. Sepanjang sejarah, tradisi batik berubah sesuai dengan keadaan, baik dari segi motif maupun teknik. Hal ini sejalan dengan pemaparan Hitchcock (1991) bahwa tradisi tekstil di Indonesia memang jarang sekali berkembang statis, karena ide-ide dan metode-metode baru dari luar senantiasa diserap dan diolah untuk menciptakan perubahan keadaan sosial dan ekonomi.

Wilayah pesisir utara pulau Jawa yang dikenal dengan daerah batik antara lain Indramayu, Cirebon, Pekalongan, Lasem, Tuban, Tanjungbumi, Pamekasan, Sumenep, dan Sidoarjo (Hasanuddin, 2001). Kain batik Sidoarjo tampak adanya percampuran gaya dari dua bahkan lebih yang diterapkan dalam setiap batiknya. Pengaruh yang masuk dalam batik Sidoarjo antara lain pengaruh budaya Islam, China, Eropa, India, dan juga pengaruh etnis pasarnya semisal Madura, Sumatera, Pesisir, dan Jawa (Ahmad, 2013).

Publikasi tentang historiografi batik wilayah pesisir yang telah dilakukan para peneliti asing secara khusus antara lain batik Tuban, Lasem, Madura, Cirebon, dan Pekalongan. Hingga kini pembahasan mengenai batik Sidoarjo masih sangat lemah dan kurang, terbukti 
dalam beberapa publikasi mengenai batik, pembahasan mengenai batik Sidoarjo nyaris tidak tersentuh. Batik Sidoarjo dalam berbagai wacana, terkesan periphery dan hingga kini kedudukannya dalam konstelasi pembatikan di Indonesia masih terkesan wilayah "abuabu" (grey area). Penulisan sejarah batik juga harus didasari pemahaman metodologi sejarah, sebagaimana diungkapkan Abbas (2014) bahwa metodologi sejarah adalah pengetahuan mutlak yang harus dimiliki oleh seorang peneliti sejarah. Sebuah narasi sejarah yang ditulis oleh peneliti atau sejarawan jelas akan berbeda dengan "cerita lisan" masyarakat umum.

Masalah fundamental dalam tinjauan atau penulisan sejarah batik adalah bias pada cerita lisan yang dianggap sebagai kebenaran dan sumber tunggal, terlebih banyak cerita yang sarat dengan kepentingan ekonomi dan politik. Bias sejarah yang sering terjadi adalah berupaya penyebutan angka tahun menjadi yang paling tua, beraroma penomorsatuan, dan selalu dikaitkan dengan masa kerajaan-kerajaan Jawa Kuno tanpa adanya dukungan sumber sejarah yang kuat.

Daliman (2012) menegaskan bahwa objektivitas harus menjadi prinsip yang tidak boleh ditinggalkan oleh sejarawan dalam merekonstruksi masa lampau yang pernah terjadi. Sebagaimana diungkapkan oleh Wasino \& Hartatik (2018) bahwa peristiwa masa lampau diangkat kembali melalui prosedur penelitian sejarah dianggap memiliki manfaat atau kegunaan bagi kehidupan manusia pada masa sekarang. Adapaun guna sejarah bagi umat manusia yang mempelajarinya antara lain untuk pendidikan, memberi pengajaran (instruktif), inspiratif dan rekreatif.

Berdasarkan perkembangan kesejarahan, keberadaan pembatikan di Sidoarjo ditengarai sudah sejak kisaran abad ke-17 bahkan usianya setara dengan pusat- pusat pembatikan daerah pesisir utara Jawa (north coast) lainnya (Ahmad, 2013). Pemahaman tentang batik Sidoarjo masih cenderung parsial, bahkan sering disebut sebagai batik Madura atau dianggap terpengaruh batik Madura. Keberadaan batik Sidoarjo hingga sekarang kurang terwacanakan keberlangsungan dan kekhasan estetiknya sebagai sebuah identitas budaya dan juga komoditas.

Ironis memang masyarakat sekarang hanya mengenal dan menyebut batik Sidoarjo sebagai batik yang kasar dan obar-abir (Ahmad, 2013). Batik Sidoarjo yang dulu memiliki karakter dan kualitas yang baik tidak banyak dikenal masyarakat secara luas. Selain itu, banyak penelitian yang hanya melakukan kajian pada kondisi sekarang dan parsial pada daerah Jetis sehingga hakikat batik Sidoarjo tidak terjelaskan secara utuh dan terjebak dalam pemahaman historisitas setempat yang kurang tepat. Akibatnya, berbagai kajian tersebut tidak berhasil mendudukkan batik Sidoarjo sesuai dengan konteksnya secara utuh, malah menjadi semacam standardisasi narasi pada karakteristik maupun sejarahnya.

Maka dari itu, penelitian ini akan mengkritisi konstruksi sejarah yang telah populer terkait pemahaman dasar tentang batik Sidoarjo. Artikel ini merupakan upaya penulis untuk memberikan analisis atau paparan yang berbeda dari narasi sejarah batik Sidoarjo yang umum dilakukan pada berbagai pembahasan. Artikel ini akan mendeskripsikan dinamika sejarah dalam perkembangan batik Sidoarjo.

\section{KAJIAN TEORI}

\section{Kritik Sejarah}

Sejarah merupakan suatu realitas peristiwa, kejadian yang berkaitan dengan perilaku dan pengalaman hidup manusia di masa silam. Seorang peneliti yang ingin merekonstruksi suatu peristiwa di masa lampau tentu harus melalui "pintu" riset. Melalui penelitian atau riset yang dilakukannya maka akan terungkap berbagai temuan yang dapat dipertanggungjawabkan secara objektif (Abbas, 2014). Pendekatan historis memiliki ciri khas menekankan aspek diakronisnya sebagai $a$ science of change, yaitu pengungkapan sejarah yang menawarkan bukan hanya struktur dan berdialektik dengan melihat realitas sejarah, melainkan mengedepankan pengungkapan kebenaran peristiwaperistiwa dari waktu ke waktu (Kuntowijoyo, 2013).

Menurut Kartodirdjo (1993), masalah pendekatan merupakan permasalahan inti dari metodologi dalam ilmu sejarah. Penggambaran mengenai suatu peristiwa sangat tergantung pada pendekatan. Maksudnya dari segi mana memandangnya, dimensi mana yang diperhatikan, unsur-unsur mana yang diungkapkan dan lain sebagainya. Jenis pendekatan yang digunakan akan menjadi penentu hasil penulisannya. Pendekatan yang bisa digunakan dalam penulisan sejarah adalah pendekatan sosiologis, pendekatan antropologis (antropologi sosial, antropologi politik, antropologi budaya), dan pendekatan politikologis.

Salah satu tahapan dalam metode penelitian sejarah adalah kritik. Irwanto \& Sair (2014) menegaskan hal utama yang mendasari munculnya pertanyaan yang pertama muncul dalam kritik adalah keraguan tentang sumber yang didapat, di mana sesuatu yang "tampaknya benar" dan bukannya sebagai benar secara obyektif. Gray (1964) menjelaskan bahwa kritik merupakan tahapan untuk menguji kebenaran 
(validitas) dari sumber sejarah. Kuntowijoyo (2013) membagi kritik menjadi dua, yaitu: (a) Kritik ekstern merupakan kegiatan untuk menguji autentisitas (keaslian) sumber. Kritik ekstern cenderung menguji keaslian sumber sejarah dari bentuk fisiknya; (b) Kritik intern untuk menguji kredibilitas dan realibilitas dari sumber sejarah. Kritik intern mengkritisi konten dan substansi isi dari sumber sejarah. Pranoto (2010) menegaskan yang dimaksud dengan kritik adalah kerja intelektual dan rasional yang mengikuti metodologi sejarah guna mendapatkan objektivitas suatu kejadian. Kritik sumber merupakan upaya untuk mendapatkan otentisitas dan kredibilitas.

Kritik sejarah adalah kritik seorang peneliti terhadap sumber-sumber sejarah yang diperolehnya. Kritik sejarah tersebut dilakukan dengan latar bahwa meskipun seorang peneliti sejarah telah yakin bahwa sumber sejarah yang telah ia peroleh benar-benar asli, ini tidak berarti bahwa segala yang dikandungnya memiliki nilai kesejarahan yang benar, tetapi masih harus dilakukan kritik sumber terhadapnya dari segisegi yang lain. Ada sumber-sumber yang menurut nama penulisnya, juga masa dan tempat itu ditulis. Ada juga sumber yang cenderung asli namun tidak memuat halhal tersebut. Hal ini tentunya dapat mengurangi nilai kesejarahan sumber sejarah yang didapat tersebut (Irwanto \& Sair, 2014). Penulisan sejarah maupun kritik yang tepat bukanlah semata-mata untuk menghasilkan karya yang bersifat kompilasi. Tetapi harus dapat memberikan sumbangan baru kepada perkembangan ilmu pengatahuan dengan menggunakan fakta baru dari penemuannya dalam melaksanakan penelitian atau interpretasi baru terhadap data yang telah lama dikenal orang (Abdurrahman, 1999).

Irwanto \& Sair (2014) menjelaskan bahwa eksplanasi dalam sejarah berkenaan dengan dua hal yaitu sintesis dan analisis terhadap fakta yang didapat dari sumber sejarah. Sintesis berkenaan dengan menguraikan berbagai fakta yang didapat dan menghubungakan dengan fakta lainnya, sementara analisis berkenaan dengan menyimpulkan beberapa fakta yang diuraikan tadi. Analisis berkenaan dengan cara menguraikan berbagai fakta sejarah dalam sumber sejarah yang didapatnya, sehingga dapat diketahui bagian-bagian yang dapat saling berhubungan antara satu dengan yang lain dalam fakta sejarah tersebut. Sintesis dalam eksplanasi sejarah menekankan eksplanasi yang dilihat dari sebab-sebab suatu peristiwa, dengan mengemukakan bahwa dalam banyak hal peristiwaperistiwa dan tindakan-tindakan harus dijelaskan melalui reasons atau nalar.

\section{Batik Pesisir}

Kenyataan sejarah menunjukkan bahwa perkembangan batik di Indonesia tidak terlepas dengan wilayah Jawa. Karakteristik pembatikan di Jawa secara mendasar digolongkan menjadi dua bagian besar, yaitu keraton (royal courts batik) dan pesisir utara (north coast batik). Batik Pesisir, yang secara sederhana merupakan istilah yang dikenakan pada batik dari luar dinding keraton. Keberadaannya tidak di bawah kendali aristokrasi keraton, sehingga ragam coraknya berkembang dinamis.

Kegiatan membatik di wilayah pesisir menjadi sebuah kegiatan usaha (kewirausahaan), bukan lagi suatu tradisi yang adiluhung milik kerajaan. Pertumbuhannya berkaitan erat dengan kegiatan perdagangan. Akibat interaksi perdagangan, ragam hias dan warnanya mendapat pengaruh dari luar. Perkembangan batik pesisiran juga tidak dapat dipisahkan dengan masa penyebaran Islam. Sebagaimana sejarah mencatat, bahwa wilayah pesisir utara Jawa disebut oleh van Leur (1955) sebagai "jalur sutera emas" yaitu merupakan kawasan lalu-lintas perdagangan yang penting, daerah kekuasaan Islam dan tempat bertemunya berbagai bangsa, yang oleh Heringa (1996) disebut juga sebagai "belanga peleburan".

Batik pesisiran adalah semua batik yang pembuatannya dikerjakan di luar daerah Solo dan Yogya, memiliki karakteristik tersendiri, motifnya bersifat naturalistik dan warnanya lebih cerah dan beragam (Djoemena, 1990b). Batik pesisir, masyarakat pembuatnya berasal dari kalangan yang tidak berinduk kepada alam pikiran keraton. Aktivitas membatik merupakan sarana untuk mengungkapkan ekspresi yang bebas dan tidak terikat pada aturan-aturan khusus. Karena itu, produk batik daerah ini memiliki corak dinamis dan beraneka ragam, dengan proses pembuatan yang efisien, cepat, dan mutu yang stabil.

Wulandari (2011) menyebutkan warna dalam batik pesisiran sangat kaya ragam biasanya menggunakan latar warna gading (jingga atau warna mangga yang hampir masak), biru tua, hijau tua, cokelat tanah, hingga ungu. Batik pesisiran memiliki ciri-ciri warna yang digunakan lebih bervariasi, banyak diantaranya mengguanakan warna sintetis, motifnya lebih variatif dan cenderung naturalistik biasanya berupa hewan dan tumbuhan (van Roojen, 2001).

Selain itu, faktor lain yang menyebabkan adanya perbedaan antara batik keraton dan pesisiran adalah fungsi batik bagi masyarakat pesisiran. Bagi mereka kain batik lebih berfungsi sebagai barang dagangan. 
Gorga : Jurnal Seni Rupa

Volume 10 Nomor 01 Januari-Juni 2021

p-ISSN: 2301-5942 | e-ISSN: 2580-2380

Sebagai barang dagangan, batik pesisiran banyak dikembangkan oleh para pedagang. Minat pasar yang besar akan jenis batik ini membangkitkan jiwa wirausaha banyak orang. Di beberapa tempat, batik pesisiran ini sempat menjadi barang dagangan sampai ke mancanegara. Hal itu menyebabkan perkembangan ragam hias dan warna batik masyarakat pesisiran mengacu pada permintaan pasar.

Pada awalnya, batik pesisir dipengaruhi oleh masuknya tekstil India dalam hal corak warna, desain motif dan layout (Majlis, 2000). Tradisi batik pesisir utara Jawa tidak terkekang oleh hukum khusus dan persyaratan ritual. Batik di kawasan ini terbuka untuk perdagangan dengan luar negeri, sangat bebas, jauh berbeda dengan batik keraton yang sarat aturan. Untuk meningkatkan keuntungan usaha, dalam industri ini digunakan pula cap logam, pewarna kimia dan para pekerja batik terorganisasi dalam industri rumahan.

Batik pantai utara juga menggunakan motif dari China, Arab, dan Eropa, yang dimodifikasi agar sesuai dengan karakter tradisi tiap tempat. Batik pesisir telah diekspor pula secara luas ke seluruh Asia Tenggara (Harris, 1993). Pengaruh Eropa dimulai pada akhir abad ke-19. Diperkenalkannya pewarna kimia, benang sintetis, pemintalan, dan inovasi alat tenun dari barat, disertai perubahan penyebaran sosial dan ekonomi, menyebabkan modifikasi yang luas terhadap tradisi tekstil lokal (Harris, 1993).

\section{METODE PENELITIAN}

Penelitian ini tergolong dalam penelitian kualitatif. Terutama untuk mengungkap realitas aktual yang terkait dengan dinamika sejarah batik Sidoarjo dalam hubungan kausalitas. Selain itu juga digunakan metode sejarah, yaitu proses menguji dan menganalisis secara kritis catatan, dokumen, dan objek peninggalan sejarah pada masa lampau. Hal ini penting, karena mengkaji persoalan aktual dengan metode sejarah memiliki kelebihan dalam hal kejelasan baik struktur maupun prosesualnya (Skocpol, 1984). Metode sejarah terdiri atas empat tahap, yaitu heuristik, kritik sumber, interpretasi, dan historiografi (Gottschalk, 1975). Penelitian ini menggunakan pendekatan historis dan sosiologis untuk mengumpulkan, menyeleksi, dan menguji secara kritis sumber-sumber sejarah batik Sidoarjo, sehingga menghasilkan fakta sejarah.

Teknik pengumpulan data dilakukan secara gabungan, melalui wawancara mendalam (indepth interview), pengamatan (observation), studi arsip dan dokumen serta studi pustaka (Garraghan, 1957). Sumber data dalam penelitian ini diperoleh dari buku teks, artikel, surat kabar serta hasil-hasil penelitian. Berbagai data kemudian dilakukan analisis deskriptif historis, yaitu suatu upaya menggambarkan perkembangan batik yang pernah terjadi di wilayah Sidoarjo.

Pertama, heuristik adalah kegiatan pengumpulan data yang berupa dokumen-dokumen tertulis dan sumber lisan sebagai sumber sejarah, baik berupa sumber primer maupun sumber sekunder. Penulis mengumpulkan sumber tertulis dan wawancara mendalam kepada para informan yang berkaitan dengan penelitian tentang batik Sidoarjo. Penentuan informan mengadopsi konsep Spradley (1997) dan Benard (1994) yang prinsipnya menghendaki seorang informan itu harus paham terhadap budaya yang dibutuhkan. Penentuan informan dilakukan menggunakan teknik snowballing, yaitu berdasarkan informasi dari informan sebelumnya untuk mendapatkan informan berikutnya hingga mendapatkan 'data jenuh' (tidak terdapat informasi baru lagi). Dengan teknik snowballing, jumlah informan menjadi tidak dibatasi jumlahnya. Karakteristik informan juga tidak ditentukan oleh peneliti, melainkan didasarkan pada rekomendasi informan sebelumnya. Melalui rekomendasi itu, peneliti segera menghubungi dan menggali data berikutnya sampai data yang diperoleh mendapatkan kesatuan yang utuh.

Kedua, kritik sumber yaitu pengujian informasi sumber sejarah melalui dua macam kritik, yaitu kritik eksteren dan kritik interen. Kritik eksteren untuk menguji otentisitas sumber dan kritik interen untuk menguji kredibilitas sumber. Pada tahap pertama dan kedua inilah lekat dengan uji kredibilitas data yang dilakukan dengan pengamatan seksama (waktu, intensitas), triangulasi (sumber, metode, waktu), diskusi (pakar, sejawat), analisis kasus negatif, dan member check.

Ketiga, interpretasi yaitu penafsiran terhadap fakta sehingga menunjukkan suatu hubungan yang logis dan kronologis mengenai peristiwa masa lampau. Faktafakta sejarah yang diperoleh diinterpretasikan sesuai dengan pendekatan dan analisis data bersifat induktif. Melaui pendekatan sosiologis, peristiwa-peristiwa sosiologis penting yang terjadi dalam perjalanan sejarah batik Sidoarjo dikelompokkan berdasarkan tonggak-tonggak sejarah mereka kemudian dikonstruksi dan diinterpretasikan. Selanjutnya terakhir tahap keempat yaitu historiografi merupakan kegiatan merekonstruksi peristiwa masa lampau dalam bentuk kisah sejarah yang sistematis, logis, dan ilmiah. 


\section{HASIL DAN PEMBAHASAN}

\section{Hasil}

Pada masa kolonialisme Hindia Belanda, daerah Sidoarjo bernama Sidokare, yang merupakan bagian dari Kabupaten Surabaya. Pada 1859, berdasarkan "Keputusan Pemerintah Hindia Belanda No. 9/1859 tanggal 31 Januari 1859 Staatsblad No. 6", daerah Kabupaten Surabaya dibagi menjadi dua bagian yaitu Kabupaten Surabaya dan Kabupaten Sidokare. Pada tanggal 28 Mei 1859, nama Kabupaten Sidokare, yang memiliki konotasi kurang bagus diubah menjadi Kabupaten Sidoarjo.

Sidoarjo merupakan sebuah kabupaten di Provinsi Jawa Timur, Sidoarjo dikenal sebagai penyangga utama perekonomian Kota Surabaya, dan termasuk kawasan Gerbangkertosusila. Sidoarjo terletak $15 \mathrm{~km}$ dari selatan kota Surabaya dengan tanah delta yang subur dan diapit oleh dua sungai, yaitu Sungai Surabaya dan Sungai Porong. Kabupaten Sidoarjo secara geografis berada di antara $112^{\circ} 5^{\prime}-112^{\circ} 9^{\prime}$ BT dan $7^{\circ} 3^{\prime}-7^{\circ} 5^{\prime} \mathrm{LS}$ dengan ketinggian antara $0-12$ meter di atas permukaan laut. Luas wilayah administrasinya adalah 71.434,25 Ha dengan batas wilayah: utara berbatasan dengan Kota Surabaya dan Kabupaten Gresik; timur berbatasan dengan Selat Madura; selatan berbatasan dengan Kabupaten Pasuruan; barat berbatasan dengan wilayah Kabupaten Mojokerto. Kabupaten Sidoarjo terdiri dari 18 kecamatan, 322 desa, dan 31 kelurahan.

Tingginya pertumbuhan penduduk di Sidoarjo bukan disebabkan karena tingginya angka kelahiran, namun lebih karena banyaknya kaum urban karena faktor perkembangan industri di Sidoarjo. Luas lahan Sidoarjo terbagi menjadi lahan pertanian: $28.763 \mathrm{Ha}$, lahan perkebunan tebu: $8.164 \mathrm{Ha}$, lahan perikanan tambak $15.540 \mathrm{Ha}$, dan selebihnya tanah pekarangan, pemukiman, industri, perumahan dan lain-lain.

Di Sidoarjo banyak terdapat kawasan-kawasan Sentra Industri Kecil dan Menengah (IKM) yang pada tahun 2008 terdiri dari 72 sentra dan 42 jenis produk. IKM memiliki keunggulan dalam penyerapan tenaga kerja. Data BPS Kabupaten Sidoarjo menyebutkan sebanyak 5.141 industri. Batik merupakan salah satu prioritas utama pengembangan potensi produk unggulan IKM yang ada di Kabupaten Sidoarjo.

Kabupaten Sidoarjo merupakan daerah pertanian yang subur sebagai lumbung pangan, mempertahankan pertanian maju menggunakan mekanisme teknologi tepat guna, disamping itu mendorong perkembangan industri yang semakin meningkat, sehingga keduanya berkembang secara serasi. Sektor peternakan dan perikanan juga sangat maju, yaitu penggemukan sapi kereman (jantan), peternakan itik, budidaya tambak windu dan bandeng, budidaya kolam ikan lele dan nila. Selain itu ada juga sektor pertambangan yaitu penambangan gas bumi dan pengelolaan garam rakyat.

Kehiduapan masyarakat di Kabupaten Sidoarjo, beragam etnis membaur bersama. Orang-orang Arab di Sidoarjo sangat dihormati karena alasan kesamaaan agama. Sedangkan hubungan dengan warga Madura dan warga keturunan China, umumnya lebih bersifat ekonomi. Hubungan tradisional antara warga Madura dengan warga Sidoarjo terjalin juga karena para Kyai (pemuka agama Islam) di Sidoarjo pada umumnya menjadi panutan bagi warga Madura di Sumenep dan Pamekasan. Peranan kyai sebagai figur sentral bagi warga Madura, sangat berperanan penting dalam setiap perubahan sosial yang terjadi di tengah masyarakat Madura.

Dua etnis pendatang, etnis Madura dan Tionghoa ke Sidoarjo ini memiliki tipologi yang hampir sama; yaitu sama-sama ulet untuk berdagang. Etnis Madura kebanyakan bergerak di sektor informal seperti di pasar-pasar tradisional sementara etnis Tionghoa kebanyakan menguasai perdagangan di sektor formal seperti di banyak pertokoan yang tersebar di Sidoarjo. Kedatangan etnis Tionghoa ke Surabaya dan Sidoarjo lambat laun semakin deras seiring dengan semakin menggeliatnya roda ekonomi kawasan ini.

Sejarah menunjukkan bahwa sejak awal mulanya, kawasan Sidoarjo memiliki potensi besar di sektor industri, sekitar tahun 1800-an hingga sekarang dikenal sebagai salah satu sentra produksi gula. Sejarah mencatat ada sekitar 10 pabrik tebu yang pernah berdiri di Sidoarjo. Mulai dari Ketegan-Taman, SruniGedangan, Buduran, Candi, Tulangan, Krembung, Wonoayu, Krian, Watu Tulis, Prambon.

Pemahaman tentang batik Sidoarjo dalam berbagai publikasi rata-rata secara serampangan menganggap batik Sidoarjo sebagai batik Madura atau dipengaruhi gaya batik Madura dan dikerjakan oleh orang Madura. Seperti misalnya, Ramadhan (2013) mengatakan bahwa pembatik di Sidoarjo umumnya adalah orangorang Madura, itu sebabnya batik Sidoarjo dan batik Madura punya karakter yang sama. Begitu pula Ishwara et al. (2011) yang mengatakan bahwa ciri-ciri batik Sidoarjo mengingatkan pada batik Madura, karena di Sidoarjo banyak bermukim orang Madura. Hasanuddin (2001), Anas et al. (1997) menuliskan bahwa corak tradisional batik Sidoarjo beragam hias flora dengan paduan warna hitam, coklat, dan merah disebut batik 


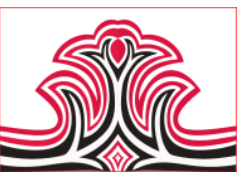

Maduran. Senada dengan Djoemena (1990a) yang mengatakan pula gaya batik Sidoarjo sangat dipengaruhi batik Madura, coraknya sejalan dengan batik Madura, warnanya merupakan adaptasi dari batik Madura. Susanto (1980) juga menyebut salah satu tipe batik Sidoarjo adalah batik Maduran.

Keberadaan pembatikan di Sidoarjo bisa dibilang cukup tua dibandingkan dengan daerah pesisir utara Jawa lainnya (Susanto, 1980). Tidak ada dokumen sejarah yang mencatat secara pasti sejak kapan batik Sidoarjo mulai muncul. Namun, bukti pernah terjadinya aktivitas pembatikan di Sidoarjo masih bisa ditemukan. Adapun cerita mengenai sejarah batik di Sidoarjo yang berkembang populer saat ini baik dalam cerita lisan masyarakat, tulisan artikel, publikasi pemerintah, dan berbagai berita di internet dinilai banyak kejanggalan, banyak keterputusan logika waktu dan konteks, perlu ditinjau ulang bahkan diluruskan. Menyebut beberapa di antaranya: Anwarid (2012), Qamariah (2012), Fitinline (2013), Wulandari et al. (2013), Tjoa (2014), Ran (2015), Wirawan \& Trilaksana (2015), Wibowo et al. (2016), Yanuar (2016), Masadmin (2016), Khasanah (2018), Arfianti et al. (2018), Listanto (2019), Solikhah (2019), Irwantono \& Hidayatun (2019), Fauzi (2020), Hani (2020)secara populer "narasi sejarah" tentang batik Sidoarjo dalam berbagai publikasi tersebut dikisahkan sebagai berikut:

"Batik Sidoarjo telah ada sejak tahun 1675, di Jetis, setahun setelah Masjid Jamik (Al-Abror) dibangun. Dimulai dari kedatangan Mbah Mulyadi seorang keturunan raja Kediri yang dikejar oleh tentara Belanda yang melarikan diri ke Sidoarjo. Mbah Mulyadi adalah ulama Mataraman pengikut Pangeran Diponegoro yang lari ke Jetis untuk menghindari kejaran Belanda. Agar terhindar dari kejaran Belanda, Mbah Mulyadi bersama para pengawalnya menyamar sebagai pedagang. Karena memiliki ketrampilan membatik, Mbah Mulyadi kemudian mengajarkan kepada orang-orang sehingga terbentuklah sebuah komunitas batik di Jetis. Selain mengajar membatik, Mbah Mulyadi juga menyebarkan syiar Islam. Dari sinilah seni batik kemudian berkembang ke daerah-daerah lain di Sidoarjo."

\section{Pembahasan}

Melalui tahap kritik eksternal dan internal, beberapa kejanggalan dalam cerita sejarah di atas bisa dikritisi sebagai berikut: a). Banyak keterputusan dan kemuskilan sejarah di sana; (1) Disebutkan "batik Sidoarjo telah ada pada tahun 1675 yang diperkenalkan oleh Mbah Mulyadi seorang pengikut Pangeran
Gorga : Jurnal Seni Rupa

Volume 10 Nomor 01 Januari-Juni 2021

p-ISSN: 2301-5942 | e-ISSN: 2580-2380

Diponegoro yang lari dari kejaran Belanda". Padahal dalam catatan sejarah ditulis bahwa era Diponegoro atau masa Perang Diponegoro terjadi pada tahun 18251830. Maka sangat salah jika tahun 1675 ada pengikut Diponegoro; (2) Penyebutan bahwa Mbah Mulyadi adalah keturunan raja Kediri juga sangatlah ambigu. Mengingat keberadaan kerajaan Panjalu (Kadiri/Kediri) adalah pada zaman Jawa kuno abad XXIII masehi, maka sangat paradoks jika disebutkan melarikan diri dari kejaran Belanda, karena masa Hindia Belanda baru mulai pada tahun 1800. Mengingat saat masa Kerajaan Panjalu (Kediri) ada 10 raja yang berkuasa dalam masa 1045-1222 masehi, maka penyebutan keturunan raja tanpa merujuk dengan pasti pada keturunan ke berapa dan keturunan raja siapa, juga makin menguatkan cerita tersebut tidak didasari sumber sejarah yang otentik dan terjebak dalam generalisasi tradisi cerita lisan.

b). Penyebutan "Batik Sidoarjo ada setahun setelah Masjid Abror dibangun" perlu dikritisi. Artikel online dalam berbagai laman dan cerita lisan masyarakat setempat menyebut bahwa Masjid Jamik (Masjid Abror) dibangun pada tahun 1674/1678. Penyebutan angka tahun ini tidak didasarkan pada sumber sejarah yang otentik. Penulis menemukan dalam catatan sejarah pembangunan masjid, bahwa masjid tersebut baru dibangun sekitar tahun 1760-an.

c). Penelurusan tentang asal usul kapan kemunculan "narasi sejarah" (cerita) tersebut dengan pendekatan politikologis ditemukan fakta ternyata cerita itu mulai dimunculkan oleh Paguyuban Batik Sidoarjo (PBS) pada saat Bupati Win Hendarso meresmikan Kampung Jetis sebagai sentra Wisata Batik pada tahun 2008. Hal ini jelas menunjukkan adanya konstruksi sejarah yang berdimensi politis dan ekonomi. Maka sangat wajar jika konstruksi sejarah itu cenderung parsial dan menomorsatukan kampung Jetis. Tidak disebutkannya wilayah pembatikan Sidoarjo lainnya menyebabkan salah pemahaman (1) bahwa pembatikan di Sidoarjo hanyalah terpusat di wilayah Jetis, (2) bahwa pertumbuhan batik di Sidoarjo cikal-bakalnya dari wilayah Jetis; (3) bahwa karakter atau ciri khas batik Sidoarjo hanyalah batik Jetis. Kesalahpahaman tersebut perlu diluruskan, karena berdasar analisis pada temuan artifak, kondisi geografis, sosial budaya, dan bangunan peninggalan maka penyebutan Jetis sebagai daerah awal tumbuhnya batik Sidoarjo adalah tidak tepat.

d). Penyebutan "Mbah Mulyadi adalah ulama Mataraman yang mengajarkan batik di Sidoarjo" menimbulkan persepsi bahwa perkembangan batik Sidoarjo mengakar pada pengaruh aristokrasi keraton. 
Cerita tersebut terjebak pada konstruksi pemahaman Mataraman, bahwa batik pasti mengakar dari keraton. Hal ini sangat menyesatkan, mengingat karakteristik batik yang ada di Sidoarjo tidak menampakkan "jejak hegemoni keraton". Selain itu dalam literatur sejarah, Sidoarjo dikenal sebagai wilayah pelabuhan dan perdagangan pesisir, maka dari itu hendaknya konstruksi sejarah berawal dari paradigma perniagaan dan secara spesifik batik Sidoarjo adalah tergolong sebagai batik Peisir.

d). Narasi Sejarah (cerita) tersebut juga "meniadakan" keterkaitan etnis China, Eropa, Arab dalam perkembangan batik Sidoarjo. Padahal dalam berbagai literatur sejarah industri, niaga dan juga tekstil khususnya, beragam etnis tersebut juga berperan serta. Selain itu bukti-bukti artifak yang mendukung keberadaan mereka dalam aktivitas pembatikan di Sidoarjo juga masih ada.

Penjelasan tentang batik Sidoarjo dalam berbagai publikasi di atas cenderung parsial dan generalisasi, umumnya hanya merujuk pada satu karakteristik batik dan ditengarai pula hanya pada satu wilayah pembatikan saja, yaitu Jetis. Belum terungkap bahwa di Sidoarjo telah berkembang juga berbagai macam karakteristik batik yang tersebar di beberapa wilayah pembatikan, bahkan pernah munculnya pembatikan dari kalangan pengusaha China Peranakan yang sangat unggul dalam kualitas maupun coraknya dan digemari kolektor dalam negeri hingga mancanegara tidak pernah disebutkan.

Wilayah pembatikan di Sidoarjo secara administratif berada di Desa Kedungcangkring (Kecamatan Jabon), Desa Jetis, Sekardangan, Gajah Mada atau China Peranakan (Kecamatan Sidoarjo), Desa Patihan, Kenongo (Kecamatan Tulangan). Perkembangan wilayah pembatikan tersebut saling terkait dalam hal keberlangsungan usaha (wirausaha) meliputi hubungan antar juragan, dukungan modal, buruh batik, tukang warna, jual beli bahan, hingga pemasaran. Selain itu juga saling mempengaruhi dalam hal corak dan perkembangan gaya batik. Ada beberapa wilayah atau desa yang bisa disebut sebagai desa pendukung industri batik, misalnya desa-desa di Tulangan (Jiken, Kenongo, Singopadu, dsb) dikenal sebagai daerah buruh batik untuk mencanting klowongan dan isen, desa Tenggulunan dikenal sebagai daerah buruh batik untuk ngeblok/nemboki. Gambar berikut ini menunjukkan skema perkembangan pembatikan di Sidoarjo.

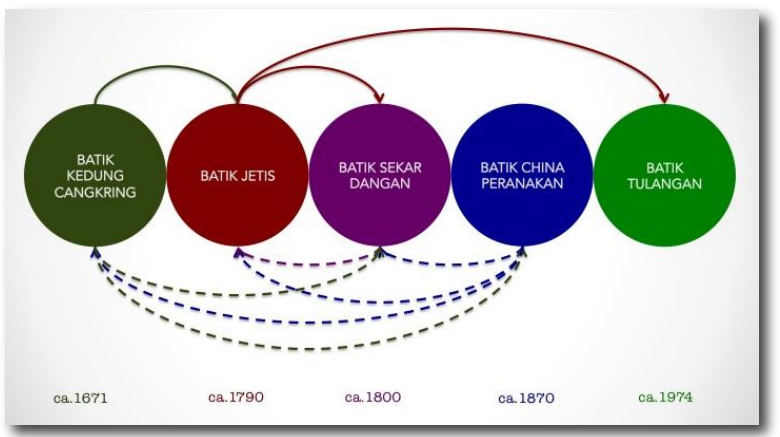

Gambar 1. Skema Perkembangan dan Keterkaitan Pembatikan di Sidoarjo. (Ahmad, 2013)

Keterangan:

- : hubungan pengaruh langsung dalam hal kemunculan usaha (wirausaha)

- . - . . : : hubungan tak langsung pengaruh corak dan gaya (tiru-meniru)

\section{1) Batik Kedungcangkring}

Kedungcangkring adalah sebuah desa yang masuk wilayah Kecamatan Jabon, Sidoarjo. Letaknya berbatasan dengan Pasuruan dan Sungai Porong. Daerah ini juga dikelilingi lahan pertanian dan pertambakan. Sesungguhnya banyak peristiwa penting terjadi di Kedungcangkring, namun sampai saat ini, masih tersaput misteri. Diperkirakan sejak abad ke-15 daerah Kedungcangkring sudah ada. Desa Kedungcangkring merupakan desa yang sangat tua di daerah perbatasan antara wilayah Sidoarjo dengan Pasuruan. Dahulu kala zaman sebelum penjajahan, desa Kedungcangkring ini sudah ada dan desa ini biasa di sebut desa pecinan yaitu desa di mana banyak suku pedatang dari China, Gujarat, Mongol.

Dikarenakan dahulunya daerah ini merupakan daerah pesisir, banyak kapal pedagang yang lewat atau singgah di daerah ini. Desa Kedungcangkring ini dahulunya merupakan desa pasar batik atau desa pusat batik karena para pedagang asing singgah di sini biasanya selain membeli rempah-rempah juga membeli batik. Bisa dibilang, Kedungcangkring adalah desa pembatikan tertua di Sidoarjo. Pembatikan di Kedungcangkring diperkirakan sekitar akhir abad ke17. Keberadaannya kala itu masih belum menjadi industri yang besar untuk menopang ekonomi. Dikisahkan, pada tahun 1671, ada saudagar Portugis yang tertarik dan membeli batik buatan masyarakat pribumi Kedungcangkring. Berawal dari itu, kemudian banyak saudagar Arab, China yang juga turut memesan.

Memasuki era pertengahan 1700-an, batik Kedungcangkring semakin meningkat. Menurut masyarakat setempat, desa Kedungcangkring sempat disebut dengan "kampung pecinan" di samping juga 


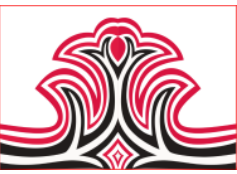

disebut sebagai "kampung batik". Konon menurut cerita yang memulai merintis tradisi batik sebagai mata pencaharian sehari-hari masyarakat adalah komunitas Tionghoa. Kala itu sebagian besar masyarakat Kedungcangkring merupakan keturunan Tionghoa Muslim.

Pembatikan di Kedungcangkring tidak hanya membuat batik tulis dan batik cap, tapi juga mengembangkan batik kombinasi, yaitu antara batik cap dan batik tulis, artinya sebagian bidang dicap sebagian bidang lainnya dicanting. Batik cap dari Kedungcangkring mampu menembus segmen pasar sampai ke seluruh Tanah Air. Diakui keunggulannya oleh kalangan konsumen dari berbagai bangsa, terutama karena nilai-nilai artistiknya dan juga karena harga jual yang relatif terjangkau. Berbagai kecenderungan trend permintaan pasar dipenuhi dengan membuat aneka cap yang sesuai dengan tuntutan dan selera pembeli.

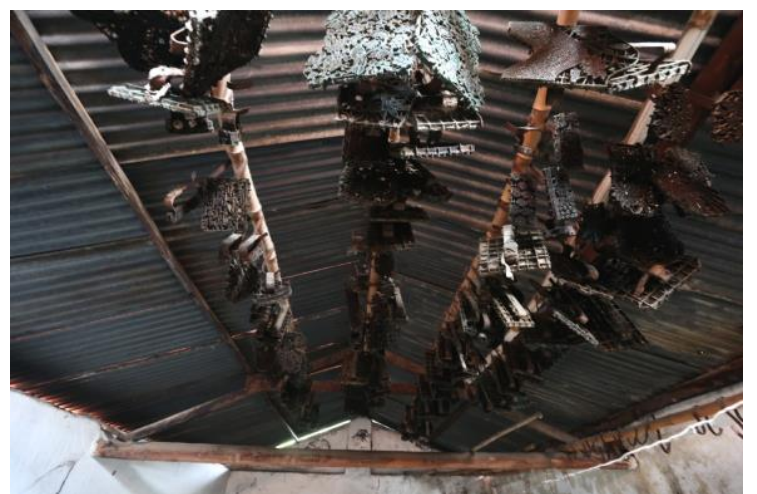

Gambar 2. Bukti Peninggalan Canting Cap di Rumah Pembatik di Kedungcangkring (Rusli, 2013)

Kemunduran batik di desa Kedungcangkring, dari banyak cerita warga disebabkan karena banyak para pedagang batik yang tidak laku jual batiknya. Disebabkan mereka kalah dengan gempuran batik printing dari Pekalongan dan Solo yang sangat murah harganya. Akhirnya mereka para pengusaha batik satu demi satu mereka menutup usaha batik mereka dan hampir atau yang terakhir itu batik masih ada pada tahun 1979, setelah itu hilang entah ke mana. Dikatakan dari sebagian warga, kebanyakan mereka pindah tempat seperti Surabaya, Pekalongan, Solo, untuk menjual batik hasil buatanya.

\section{2) Batik Jetis}

Batik Jetis merupakan batik yang dihasilkan di dusun Jetis dan Pekauman (sekarang: Pandean), kelurahan Lemahputro kecamatan Sidoarjo. Pekauman letaknya di samping Masjid Al Abror. Secara geografis dua wilayah ini dipisahkan oleh sungai, sehingga orang sering menyebutnya Jetis Kulon Kali dan Jetis Wetan Kali. Daerah sekitar Masjid Al Abror pada masa awal
Gorga : Jurnal Seni Rupa

Volume 10 Nomor 01 Januari-Juni 2021

p-ISSN: 2301-5942 | e-ISSN: 2580-2380

kabupaten Sidoarjo tahun 1859 merupakan alun-alun kota, yang sekarang telah bertransformasi menjadi pusat pertokoan.

Keberadaan Masjid Al Abror itu sendiri perkembangannya bertahap melewati masa kurang lebih 200 tahun. Sebelum adanya bangunan masjid, terlebih dulu ada sebuah bangunan yang menyerupai "gerbang" di sebelah utara masjid, gerbang ini diperkirakan berangka tahun ca. 1678. Kemudian mulailah tanah di sebelah gerbang ini dibangun pondasi dan kerangka untuk masjid pada tahun 1760. Pada tahun 1830-an barulah kerangka masjid tersebut dibangun oleh Mbah Mulyadi (pengikut pangeran Diponegoro) dibantu oleh Mbah Sayyid Salim, Mbah Muso, dan Mbah Badriyah. Kemudian pada tahun 1859 masjid ini direnovasi oleh bupati pertama Sidoarjo, RTP. Tjokronegoro.

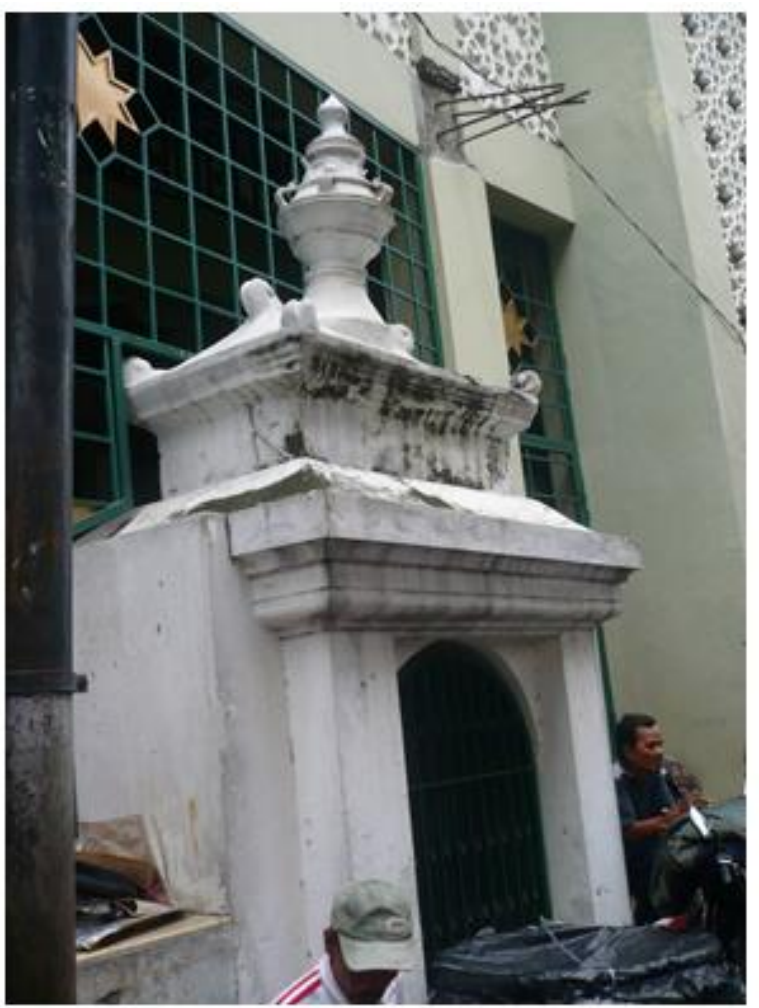

Gambar 3. Bangunan Semacam Pintu Gerbang, Berangka Tahun ca. 1678, yang Berada di Luar Sisi Sebelah Utara Masjid Abror. Merupakan Bukti Otentik Fisik Tertua di Area Masjid Abror (Ahmad, 2013)

Mbah Mulyadi adalah ulama keturunan bangsawan era Mataraman Islam-bukan keturunan raja Kediriseringkali dikisahkan bahwa dialah yang mengajarkan batik pada masyarakat Jetis. Kisah ini tidak sepenuhnya salah, namun lebih tepatnya jika disebut dia adalah yang memberitakan, menceritakan, atau memotivasi penduduk Jetis untuk mengembangkan budaya membatiknya menjadi salah satu kegiatan ekonomi, bukan mengajar teknik membatik. Karena jauh sebelum kedatangan Mbah Mulyadi di Jetis, 
masyarakat telah membatik untuk kegiatan mengisi waktu.

Perkembangan batik di Jetis berkaitan dengan Kedungcangkring. Pembatikan di Jetis mulai sekitar tahun 1790, yang dilakukan oleh beberapa pendatang China. Keberhasilan pembatikan saudagar China di Kedungcangkring, membawa pengaruh pada beberapa saudagar China di Jetis untuk ikut membuka usaha batik.

Batik Jetis mengalami booming sebagai bentuk keberlangsungan usaha sekitar tahun 1890-an. Tenaga pembatik atau buruh batik di Jetis selain masyarakat setempat juga banyak yang berasal dari Tulungagung dan Tulangan. Pola kerja tukang batik ini masih sangat dipengaruhi siklus pertanian. Saat berlangsung masa tanam dan masa panen mereka sepenuhnya bekerja di sawah. Namun, di antara masa-masa tersebut, mereka bekerja sepenuhnya membatik. Memasuki periode 1900-an pembatikan di Jetis mengalami fase disiplin kerja. Pengusaha batik yang sebagian besar keturunan China mengelola kegiatan usaha batik secara intensif. Adalah "Wan-Nyonya" salah seorang juragan batik keturunan China di Jetis yang berasal dari Gresik pada tahun 1908. Batiknya memiliki keunggulan pada karakteristik pewarnaannya.

Rata-rata pengusaha batik pribumi yang ada di Jetis pada awalnya adalah buruh batik pada juragan China. Setelah memiliki cukup modal, mereka kemudian membuka usaha sendiri. Tahun 1922, desa Jetis mempunyai predikat sebagai "kampung batik". Hampir di setiap rumah bisa ditemukan orang sedang membatik. Selain orang China, juragan batik di Jetis juga dari kalangan wong kaji. Salah satu pembatikan wong kaji yang sangat dikenal adalah $\mathrm{Hj}$. Mahmudah, yang merupakan generasi pertama yang melanjutkan kesuksesan ibunya. Pembatikan $\mathrm{Hj}$. Mahmudah berada di Pekauman, dekat Masjid Abror, dan mengalami masa booming sekitar tahun 1935.

Batik Jetis awalnya merupakan komoditas dagang yang ditujukan untuk segmen masyarakat Sidoarjo golongan menengah ke bawah. Kemudian berkembang mencakup masyarakat Madura, dan pesisir utara Jawa. Namun pada perkembangannya kemudian, lebih dominan pada masyarakat madura, sehingga menjadi dikenal dengan sebutan "batik maduran" yang bagi masyarakat Madura menyebutnya dengan "Batik Storjoan". Batik Storjoan ini mulai muncul sekitar tahun 1942. Penjualannya di Pasar Pabean dan Pasar Besar Surabaya, orang Madura beli di sana. Kemudian sekitar tahun 1950, pembatikan China di Jetis memunculkan batik gaya Laseman. Secara mendasar batik gaya Laseman ini terpengaruh dari batik tiga negeri Pekalongan. Meskipun disebut batik Laseman, dibuatnya tetap di Jetis dan pasar utamanya masih tetap masyarakat Madura.

Salah satu perusahaan batik yang sangat terkenal di kalangan masyarakat Madura adalah pembatikan milik Ny. Widiarsih yang akrab dipanggil Ny. Wida. Pembatikan Ny. Wida ini khusus hanya membuat Batik Storjoan. Perusahaan ini berdiri pada tahun 1956 dan hingga kini masih eksis dikelola oleh Dwi-Tjahjo. Hingga kini, masyarakat Madura masih sangat fanatik dengan batik Ny.Wida.

Pada tahun 1970-an, seiring era batik revival, industri batik di Jetis meningkat tajam dan menjadi salah satu tiang penopang ekonomi utama dari hampir seluruh rumah tangga di kampung Jetis. Sebagai gambaran, sesuai dengan informasi yang diperoleh diperkirakan sekitar $90 \%$ penduduk Jetis khususnya perempuan bekerja membatik. Murahnya harga batik Jetis menjadikannya tetap bisa bertahan dikala gempuran batik printing. Pada masa pertengahan 70-an itu, pembatik Jetis menerima banyak pesanan dari Jakarta. Selain itu fanatisme masyarakat Madura juga menjadi faktor eksistensi batik Jetis. Beberapa nama pembatikan yang masih eksis hingga sekarang antara lain Batik Kamsatun, Batik Amri, Batik Daun, Batik Adam, Batik Namiroh, Batik Yassaroh, Batik Maduratna Ny.Wida, dan masih banyak lagi lainnya. Selanjutnya pada perkembangan berikutnya Pemkab Sidoarjo pada tahun 2008 mengembangkan daerah ini menjadi sektor pariwisata Kampoeng Batik Jetis.

\section{3) Batik Sekardangan}

Desa Sekardangan terletak tidak jauh dari Jetis. Situasi geografis Sekardangan sekarang jauh berbeda dengan dulu ketika masa sebelum kemerdekaan. Dulu daerah Sekardangan banyak lahan pertanian, yang sekarang sudah berubah menjadi daerah pemukiman padat penduduk. Pembatikan di Sekardangan sudah terkubur seiring perkembangan zaman. Eksistensi Sekardangan sebagai daerah sentra pembatikan berlangsung hingga tahun 1990-an. Sekarang mulai ada lagi dua orang yang memulai usaha batik di Sekardangan, yaitu Ibu Sugiarti dan bapak Chusairi, itupun hanya sebagai usaha sampingan yang produksinya tidak rutin.

Keberadaan batik Sekardangan berkaitan dengan Jetis, tumbuh hampir bersamaan dengan Jetis. Kapan awal mulanya batik di Sekardangan tidak diketahui secara pasti. Sama halnya Jetis, yang mengangkat batik Sekardangan menjadi suatu usaha perekonomian juga 
kalangan China Peranakan. Hubungan Sekardangan dan Jetis pada awalnya sangat harmonis, hubungan sebagai sesama China yang mengembangkan usaha yang sama. Pembatik Sekardangan selalu membeli bahan pewarna dari Jetis, diceritakan bahwa yang mengajari teknik pewarnaan di Sekardangan adalah salah seorang juragan batik China dari Jetis. Namun, akhirnya dua klan ini menjadi bermusuhan karena batik Sekardangan jadi lebih laku di pasaran. Di samping itu nama Batik Sekardangan yang telah begitu terkenal, dijadikan merk dagang oleh beberapa pedagang. Bahkan para pengrajin batik di Jetis saat itu kemudian marak membuat batik gaya Sekardangan.

Dulu batik Sekardangan dikenal sebagai batik kelas atas, harganya lebih mahal dari Jetis dan konsumennya memang kalangan ekonomi atas. Kualitasnya bagus baik dari segi goresan canting dan warna. Pasar batik Sekardangan kebanyakan adalah para juragan tambak dan kalangan wong kaji. Selain itu, batik Sekardangan juga dipasarkan melalui para pedagang batik di Gresik dan wilayah pesisir utara lainnya. Merupakan nilai prestise tersendiri kala itu jika masyarakat mampu membeli dan memakai batik Sekardangan. Bahkan di Pegadaian batik Sekardangan bisa digadai dan dihargai tinggi.

Pola kerja pembatikan di Sekardangan kala itu masih sangat dipengaruhi siklus pertanian. Saat berlangsung masa tanam dan masa panen mereka sepenuhnya bekerja di sawah. Namun, di antara masa-masa tersebut, mereka bekerja sepenuhnya membatik. Sekitar tahun 1898 batik Sekardangan mengalami booming, waktu itu ada rombongan Belanda yang memborong habis semua batik Sekardangan dan beberapa dari rombongan itu ada yang tidak kebagian. Akhirnya rombongan itu memesan juga dalam jumlah yang cukup banyak, sekitar 600 lembar, karena kejadian itu hampir semua warga berkosentrasi dan larut dalam pekerjaan membatik sehingga pertanian mereka rusak dan gagal panen. Setelah masa itu, batik Sekardangan menurun drastis.

Hingga masuk periode 1970-an Sekardangan tidak mampu bersaing dengan gempuran batik printing, akibatnya mulai periode ini juga kualitas garapan batik Sekardangan menurun, mereka pun akhirnya membuat batik dengan harga murah atau "kualitas kasar". Surutnya pasar dan semakin meningkatnya industrialisasi di daerah sekitar Sekardangan, menyebabkan banyak warga yang kemudian lebih memilih bekerja di pabrik.
Gorga : Jurnal Seni Rupa

Volume 10 Nomor 01 Januari-Juni 2021

p-ISSN: 2301-5942 | e-ISSN: 2580-2380

\section{4) Batik China Peranakan Sidoarjo}

Batik China Peranakan Sidoarjo sebenarnya tidak jauh berbeda dengan gaya batik China di daerah lainnya. Meskipun sebagian besar juragan batik di Sidoarjo memang keturunan China, namun batik China Peranakan ini harus mendapat porsi tersendiri, karena gaya ungkap dan pasar yang berbeda. Pembatikan China Peranakan ini sekarang sudah tidak ada lagi, masa keemasannya bertahan hingga sekitar 1940-an. Pembatikan China ini terletak di Jl. Gajah Mada, yang memang sejak dulu dikenal sebagai kawasan pecinan. Daerah ini sekarang merupakan daerah sentra pertokoan di Sidoarjo.

Sejarah menyebutkan telah ada hubungan hubungan politik maupun hubungan perdagangan China dan Nusantara. Hubungan tersebut kian hari kian meningkat dan mencapai puncaknya sekitar abad ke13. Orang-orang China mulai mendirikan pemukimanpemukiman, terutama di bandar-bandar penting sepanjang pantai utara pulau Jawa, dan lambat laun berbaur dengan penduduk asli. Masyarakat keturunan mereka disebut "peranakan". Banyak di antara mereka kemudian menetap di Pulau Jawa dan hidup sebagai pedagang di kota-kota pelabuhan.

Komunitas Tionghoa di Kabupaten Sidoarjo, Jawa Timur, sudah ada sejak lama, tidak ada catatan pasti. Orang-orang Tionghoa yang memang punya bakat dagang kemudian membuka usaha di kawasan Jalan Gajah Mada dan Jalan Hang Tuah (nama sekarang). Makin lama makin banyak, sehingga kawasan Gajah Mada dan sekitarnya berkembang menjadi "pecinan" Sidoarjo. Bahkan di jalan Gajah Mada pernah didirikan pula sekolah khusus Tionghoa bernama Chung Hua Siao Siuk, sekolah ini dibubarkan oleh rezim orde baru pada tahun 1960-an. Pola permukiman etnis Tionghoa macam ini juga terjadi di kota-kota lain. Tidak direkayasa penguasa, apalagi pengembang, tapi semata-mata karena kesamaan nasib dan lahan usaha.

Bukti keberadaan komunitas Tionghoa di wilayah Gajah Mada dan Hang Tuah adalah Kelenteng Tjong Hok Kiong. Kelenteng ini didirikan sekitar tahun 1869. Dua tiang pemancang yang berdiri di depan Klenteng menandai bahwa klenteng ini merupakan klenteng Makco, yaitu Dewi Bahari pelindung para pelaut Tionghoa. Selain itu, keberadaan kelenteng Makco juga menandakan bahwa daerah Sidoarjo memang merupakan daerah pelabuhan dan lintas perdagangan jalur yang penting. 


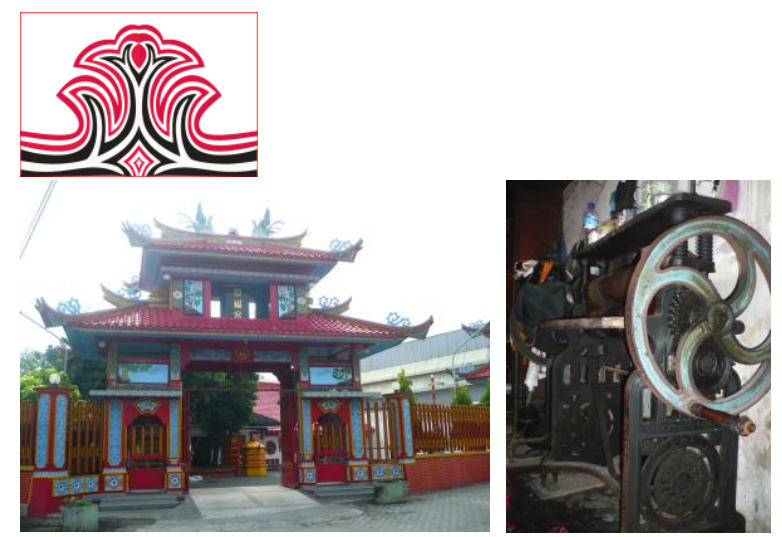

Gambar 4. Kiri: Klenteng Tjong Hok Kiong Sidoarjo, ca.1869; Kanan: Alat Press Batik, Peninggalan Pembatikan Tan Sing Ing (Ahmad, 2013)

Orang-orang China yang awalnya hanya berdagang, mulai membuat batik yang pada mulanya hanya untuk perlengkapan upacara agama dan untuk masyarakat peranakan sendiri. Orang-orang China-yang dikenal sangat mahir dalam bidang perniagaan - selalu cepat membaca iklim pasar di setiap perubahan zaman. Dua pembatikan China Peranakan Sidoarjo yang tenar adalah Tan Sing Ing dan Liem Sie Hok. Tidak begitu banyak detail cerita yang bisa dikuak tentang dua pembatik China ini. Kedua pembatikan China Peranakan ini muncul sekitar pertengahan abad ke-19. Mereka adalah wanita pengusaha batik. Pembatik Tan Sing Ing muncul lebih dulu daripada Liem Sie Hok. Tan Sing Ing dikenal sebagai keluarga pedagang yang kaya raya. Tan Sing Ing memiliki dua saudara perempuan, konon menurut cerita, dia tidak memiliki keturunan. Sedangkan nama Liem Sie Hok sendiri bukanlah nama aslinya, namun merupakan nama suaminya. Setalah suaminya meninggal dunia, karena ketenaran nama suaminya sebagai seorang saudagar tembakau maka diapakailah namanya menjadi trademark batiknya. Batik Tan Sing Ing maupun Liem Sie Hok sangat mahal harganya, konsumennya kebanyakan kalangan Indo-Eropa di samping China Pesisir Utara Jawa dan kalangan borjuis juragan tambak di Sidoarjo.

Melihat perkembangan batik Belanda yang digemari masyarakat Indo-Belanda dan bahkan juga kalangan China sendiri, para pengusaha batik China ini segera memproduksi batik-batik yang pola, warna, serta gayanya senada dengan batik Belanda. Sekitar tahun 1910-1930, motif buketan gaya batik Indo-Eropa diadopsi sebagai motif dalam batik China Peranakan. Hal ini dilakukan sebagai upaya komunitas China Peranakan_yang jauh sebelumnya telah beregenerasi di kawasan pesisir utara Jawa — untuk menunjukkan kesamaan strata sosialnya dengan kalangan Indo-Eropa dan menunjukkan tingginya capaian estetik mereka yaitu menggabungkan kedua elemen budaya Jawa dan Eropa.
Gorga : Jurnal Seni Rupa

Volume 10 Nomor 01 Januari-Juni 2021

p-ISSN: 2301-5942 | e-ISSN: 2580-2380

Batik-batik China yang dibuat sesudah tahun 1910 banyak yang dianggap sebagai adikarya di samping batik-batik Belanda. Sebelum tahun 1910 batik China masih menggunakan ragam hias dari mitologi China. Sesudah 1910 pola dan ragam hiasnya mengandung unsur budaya Eropa, meskipun dengan tata warna berbeda. Akhirnya batik buatan orang-orang China tidak hanya masuk di lingkungan masyarakat peranakan, tetapi juga menembus pasar orang-orang Indo-Belanda.

Orang China ahli dalam eksperimen pewarnaan sintetis pada batik, hasil eksperimen warnanya disimpan sebagai resep rahasia perusahaan, maka dari itu karakter warna dari perusahaan batik China jauh berbeda dengan batik dari kalangan pribumi. Batik yang diproduksi oleh pengusaha China umumnya dikerjakan oleh para pekerja pribumi dengan aturan dan disiplin ketat. Karena itu mutu batik produksi pengusaha China umumnya baik. Pengusaha China adalah orang pertama yang melakukan eksperimen pewarna sintetis untuk batik. Hasil eksperimen ini biasanya disimpan sebagai rahasia perusahaan. Batik produksi pengusaha China cenderung menggunakan warna-warna terang dan beraneka. Jenis pewarna yang dipakai umumnya adalah indigosol yang tahan terhadap gosokan dan sinar matahari. Indigosol bersifat mudah larut dalam air sehingga memiliki daya afinitas yang baik terhadap katun.

\section{5) Batik Tulangan}

Tulangan merupakan sebuah kecamatan. Daerah yang dikelilingi oleh lahan pertanian dan perkebunan yang merupakan penopang ekonominya. Tulangan sejak masa kolonial merupakan lahan tebu yang besar, karena di sana ada satu pabrik gula milik Belanda. Tulangan pada awalnya bukan merupakan wilayah pembatikan, namun sejak dulu banyak penduduk dari Tulangan yang berprofesi sebagai buruh batik di sela-sela aktivitas pertaniannya. Mereka menjadi buruh batik pada para pengusaha batik di Kedungcangkring, Jetis, dan Sekardangan. Beberapa desa di Tulangan yang dikenal sebagai desa para buruh batik adalah Singopadu, Kepatihan, Kenongo, Jiken. Batik Tulangan dalam perkembangannya kini dikenal sebagai batik kontemporer.

Tumbuhnya Tulangan secara khusus sebagai wilayah pembatikan terjadi pada era batik revival. Awalnya dirintis oleh Alm. H. Oesman Yasir sebagai usaha keluarga pada tahun 1974 di Desa Kenongo, Kecamatan Tulangan. Nama Batik Kenongo sendiri berasal dari nama desa tempat usaha batik tersebut. Batik Kenongo merupakan batik tulis asli dan proses 
pembuatannya masih tradisional yakni dengan memanfaatkan para pembatik dari penduduk setempat. Produk pertama yang dihasilkan yaitu kain panjang dan sarung dengan corak yang masih memakai pakem batik klasik (Yogya-Solo).

H. Oesman Yasir pada tahun 1974-an lebih banyak membidik warga Madura untuk memasarkan batiknya karena daya beli masyarakat di sekitar Sidoarjo rendah. Kemudian usaha batiknya ini berkembang pada tahun 1980-an terdapat penambahan motif batik lainnya yaitu motif bayeman dan motif iris tempe serta penggunaan perpaduan warna yang disesuaikan dengan selera masyarakat. Kemudian Pada Tahun 1985-an banyak permintaan dengan motif baru tersebut dan membuat Batik Kenongo lebih dikenal di luar Sidoarjo dan mencapai kejayaannya di tahun 1990-an. Tahun $1997-$ an H. Oesman Yasir meninggal dunia dan usaha batik tersebut kemudian dilanjutkan oleh anaknya.

Tumbuhnya Tulangan ini sebagai desa batik baru, juga merupakan upaya dari Paina Hartono dengan merk Batik Sari Kenongo. Sejak tahun 1998 di kala himpitan krisis moneter, ia mengajak hampir seluruh ibu rumah tangga dan remaja bekerja sebagai pembatik. Memang sebenarnya di Desa Kenongo yang terletak di sebelah Desa Patihan, juga sudah ada sebuah industri batik, tetapi industri itu tidak banyak menampung tenaga kerja. Justru dengan kehadiran Paina Hartono semakin banyak warga desa yang mengenal dan mau bekerja membatik. Saat itu jumlah pembatik di Desa Patihan dan Desa Kenongo sebanyak 700 orang.

\section{KESIMPULAN DAN SARAN}

\section{Kesimpulan}

Batik Sidoarjo ketika masa pemerintahan kolonial sudah begitu dikenal, bahkan keberadaannya ditengarai sejak masa penyebaran Islam pada kisaran abad ke-17. Pada dasarnya terminologi batik Sidoarjo merujuk pada batik yang dihasilkan dari aktivitas pembatikan-baik itu pembatikan China peranakan maupun pribumiyang ada di Sidoarjo yaitu mencakup wilayah Kedungcangkring, Jetis, Sekardangan, Jl. Gajah Mada, dan Tulangan. Tiap wilayah pembatikan tersebut memiliki karakteristik masing-masing. Kesemuanya saling terkait memiliki hubungan langsung dalam hal kemunculan usaha pembatikan. Kemunculan pembatikan di wilayah Kedungcangkring ditengarai mulai tahun ca.1671, Jetis tahun ca.1790, Sekardangan tahun ca.1800, China Peranakan (Jl. Gajah Mada) tahun ca.1870, dan Tulangan tahun ca.1974.

Hadirnya golongan masyarakat atau bangsa lain seperti China Peranakan, Indo- Eropa, Belanda, Arab turut berpengaruh melahirkan batik Sidoarjo. Adaptifnya produk batik Sidoarjo terhadap selera pasar dan pengaruh dari budaya lain, mencerminkan kemampuan segolongan masyarakat Sidoarjo dalam mengambil unsur-unsur budaya lain tanpa meninggalkan budaya tradisionalnya. Hal tersebut menunjukkan bahwa masyarakat di Sidoarjo memiliki sikap open minded tolerance atau savoir vivre (lapang dada) dalam menanggapi kebudayaan asing yang hadir.

Secara skala usaha, hanya Jetis dan Tulangan yang melakukan produksi setiap harinya dan menyerap cukup banyak tenaga kerja. Sedangkan di Sekardangan hanya tinggal dua pengrajin saja, itupun skala produksinya sangat kecil. Lain halnya dengan di Kedungcangkring, saat ini ada satu pengrajin yang berupaya menghidupkan kembali produksi batik. Pembatikan di Kedungcangkring secara masif sudah tidak ada lagi, bahkan bisa dibilang pada kisaran akhir masa '70-an sudah berhenti total. Begitu pula dengan pembatikan di Jl. Gajah Mada yang merupakan industri batik China Peranakan juga sudah tidak ada.

Pembatikan di Sidoarjo telah mengalami pertumbuhan dengan berbagai aspeknya. Pertama, batik sebagai kegiatan sambilan. Kedua, batik sebagai komoditas dagang. Ketiga, batik sebagai bentuk wirausaha. Pertumbuhan batik Sidoarjo dipengaruhi oleh dua faktor yaitu pertama sifat pekerjaan membatik di Sidoarjo adalah pekerjaan sambilan, yaitu di sela-sela pekerjaan utama bertani, dan tambak. Faktor kedua adalah sifat produk batik sebagai komoditas dagang, diciptakan (diproduksi) berdasarkan pertimbangan konsumen.

\section{Saran}

Penelitian tentang batik Sidoarjo masih bisa dikembangkan lebih luas. Batik Sidoarjo bisa dikaji secara mendalam pada persoalan transformasi budaya, interpretasi pemaknaan, bahkan pergeseran nilai estetik. Persoalan yang menyangkut aspek kesejarahan dalam dinamika batik Sidoarjo belum tuntas, historiografi batik Sidoarjo masih bisa dikembangkan lebih luas dikaitkan dengan latar sejarah masa perniagaan dan penyebaran Islam, masa kolonialisme Belanda, serta masa pascakemerdekaan RI dengan pendekatan sosio historis atau mungkin juga antropologi kebudayaan.

\section{DAFTAR RUJUKAN}

Abbas, Irwan. (2014). Memahami Metodologi Sejarah antara Teori dan Praktek. ETNOHISTORI: Jurnal Ilmiah Kebudayaan dan Kesejerahan, 1(1), 33-41. 


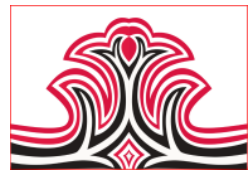

Abdurrahman, Dudung. (1999). Metode Penelitian Sejarah. Yogyakarta: Logos.

Ahmad, Asy Syams Elya. (2013). Kajian Estetik Batik Sidoarjo. Tesis. Tidak Diterbitkan. Bandung: Program Studi Magister Desain, Institut Teknologi Bandung.

Anas, Biranul, Hasanuddin, Ratna Panggabean, Yanyan Sunarya. (1997). Indonesia Indah-Buku ke 8; "Batik". Jakarta: Yayasan Harapan Kita/BP 3 TMII.

Anshori, Yusak \& Kusrianto, Adi. (2011). Keeksotisan Batik Jawa Timur. Jakarta: Elex Media Komputindo.

Anwarid. (2012). Geliat Batik Tulis Sidoarjo. Skripsi. Tidak Diterbitkan. Surabaya: Jurusan Pengembangan Masyarakat Islam, Fakultas Dakwah, Institut Agama Islam Negeri Sunan Ampel.

Arfianti, D. Y., Afandi, A. F., permatasari, i., Agustin, F. R., \& Nikmah, K. (2018). Batik Jetis Sidoarjo. https://doi.org/ 10.31227/osf.io/xq3r2 (diakses tanggal 17 April 2021).

Benard, Russell H. (1994). Research Methods in Anthropology. London: Sage Publications.

Carey, Peter. (1996). “The World of the Pasisir”, dalam Fabric of Enchantment; Batik from the North Coast of Java. County Museum of Art.

Daliman. (2012). Metode Penelitian Sejarah. Yogyakarta: Ombak.

Djoemena, Nian S. (1990a). Batik dan Mitra. Jakarta: Djambatan.

, Nian S. (1990b). Ungkapan Sehelai Batik: Its Mystery and Meaning. Cetakan II. Jakarta: Djambatan.

Elliott, Inger McCabe. (2004). Batik, Fabled Cloth of Java. Singapore: Periplus.

Fauzi, Ahmad. (2020, Juli 24). Daya Tarik Kampung Batik Jetis Sidoarjo. https://brisik.id/read/ 54889/daya-tarik-kampung-batik-jetis-sidoarjo (diakses tanggal 17 April 2021).

Fitinline. (2013, Februari 17). Batik Sidoarjo. https:/fitinline.com/article/ read/batik-sidoarjo/ (diakses tanggal 17 April 2021).

Garraghan, Gilbert J. 1957. A Guide To Historical Method. New York: Fordham University Press.

Gottschalk, Louis. (1975). Mengerti Sejarah. Terjemahan Nugroho Notosusanto. Jakarta: Yayasan Penerbit UI.

Gray, Wood. (1964). Historian's Handbook: A Key to the Study and Writing of History. Boston: Houghton Mifflin.

Gustami, SP. (2007). Butir-butir Estetika Timur; Ide Dasar Penciptaan Seni Kriya Indonesia. Yogyakarta: Prasista.
Gorga : Jurnal Seni Rupa

Volume 10 Nomor 01 Januari-Juni 2021

p-ISSN: 2301-5942 | e-ISSN: 2580-2380

Hani, Asfi. (2020, September 18). Sejarah Batik di Kampung Batik Jetis Sidoarjo. https://www. kompasiana.com/asfihani5098/5f642741097f3 602e03e3cc3/sejarah-batik-di-kampung-batikjetis-sidoarjo?page=all (diakses tanggal 17 April 2021).

Hasanuddin. (2001). Batik Pesisiran: Melacak Etos Dagang Santri pada Ragam Hias Batik. Bandung: Kiblat.

Harris, Jennifer, Ed. (1993). 5000 Years of Textiles. London: The British Museum Press.

Hitchcock, Michael. (1991). Indonesian Textiles. Periplus Editions (HK) Ltd.

Heringa, Rens \& Veldhuisen, H.C. (1996). Fabric of Enchantment; Batik from the North Coast of Java. Los Angeles: County Museum of Art.

Heringa, Rens. (2010). "Upland Tribe, Coastal Village, and Inland Court: Revised Parameters for Batik Research" dalam Five Centuries of Indonesian Textiles. Ruth Barnes \& Mary Hunt Kahlenberg (Ed). Munich: Prestel.

Irwanto, Dedi \& Sair, Alian. (2014) Metodologi dan Historiografi Sejarah. Yogyakarta: EJA PUBLISHER.

Irwantono, Yusuf \& Hidayatun M.I. (2019). Fasilitas Wisata Edukasi Batik Sidoarjo di Sidoarjo. Jurnal eDIMENSI ARSITEKTUR, 7(1), 10891096.

Ishwara, Helen, L.R. Supriyapto Yahya, Xenia Moeis. (2011). Batik Pesisir Pusaka Indonesia; Koleksi Hartono Sumarsono. Jakarta: KPG.

Kartodirdjo, Sartono (1993). Pendekatan Ilmu Sosial dalam Metodologi Sejarah. Jakarta: Gramedia.

Khasanah, Uswatun. (2018, Juni 8). Batik Asli Sidoarjo.https://doi.org/ 10.31227/ osf.io/zdka8 (diakses tanggal 17 April 2021).

Kuntowijoyo. (2013). Pengantar Ilmu Sejarah. Yogyakarta: Tiara Wacana.

Listanto, Virgiawan. (2019). "Batik Sebagai Representasi Produk Indsutri Kreatif di Sidoarjo Reinvensi Pragmatis untuk Inovasi Industri Kreatif Berbasis Budaya Visual Nusantara." Prosiding Seminar Nasional Seni dan Desain 2019, 465-469. Surabaya: Universitas Negeri Surabaya.

Majlis, Brigitte Khan. (2000). "Javanesse Batik: An Introduction" dalam Rudolf G. Smend, Batik from The Courts of Java and Sumatra. Singapore: Periplus.

Masadmin, (2016, Oktober 3). Batik Jetis Sidoarjo. Badan Perpustakaan dan Kearsipan Provinsi Jawa Timur. https:// jawatimuran.disperpusip. jatimprov.go.id/2016/10/03/batik-jetis-sidoarjo/ (diakses tanggal 17 April 2021). 


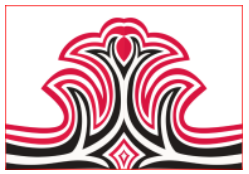

Maxwell, Robyn. (2003). Textiles of Southeast Asia: tradition, trade and transformation. Hongkong: Tuttle.

Pranoto, Suhartono W. (2010). Teori dan Metodologi Sejarah. Yogyakarta: Graha Ilmu.

Qamariah, Desti. (2012). Perkembangan Motif Batik Tulis Jetis Sidoarjo (2008-2011). Skripsi. Tidak Diterbitkan. Malang: Program Studi Pendidikan Sejarah, Fakultas Ilmu Sosial, Universitas Negeri Malang.

Ran. (2015, Desember 5). Sempat Tenggelam, Kini Kian Eksis: Sejarah Panjang Batik Sidoarjo. Jawa Pos. https://www.pressreader.com/indone sia/jawa-pos/20151205/282656096383339 (diakses tanggal 17 April 2021).

Ramadhan, Iwet. (2013). Cerita Batik. Tangerang: Literati.

Rouffaer, G.P. \& Juynboll, H.H. (1914). De Batikkunst in Nederlandsch Indië en haar geschiedenis. Utrecht: Oosthoek.

Rusli. (2013). "Pendokumentasian Artifak Sejarah Pembatikan di Kedungcangkring". Hasil Dokumentasi Pribadi: 2 Februari 2013. Kedungcangkring, Sidoarjo.

Skocpol, Theda (ed.). (1984). Vision and Method in Historical Sociology. Cambridge: Cambridge University Press.

Solikha, Rokhimatus. (2019). Sejarah Perkembangan dan Pengaruh Batik Jetis dalam Perekonomian Masyarakat Desa Jetis Sidoarjo. Skripsi. Tidak Diterbitkan. Surabaya: Program Studi Sejarah Peradaban Islam, Fakultas Adab dan Humaniora, Universitas Islam Negeri Sunan Ampel.

Spradley, James. (1997). Metode Etnografi. Yogyakarta: Tiara Wacana.

Susanto, Sewan. (1980). Seni Kerajinan Batik Indonesia. Jakarta: Balai Penelitian Batik dan Kerajinan. Lembaga Penelitian dan Pendidikan Industri, Departemen Perindustrian RI.

Tjoa, Dave. (2004, Oktober 5). Batik Sidoarjo: Kampung Batik Jetis, Kampung Pengrajin Batik Tulis Sidoarjo. http://jejakbatik.blogspot. com/2014/10/batik-sidoarjo.html (diakses tanggal 17 April 2021).

van Leur, J.C. (1955). Indonesian Trade and Society: Essay in Asean Social and Economical History. 's-Gravenhage: n.v. Uitgeverij W. Van Hoove.

van Roojen, Pepin. 2001. Batik Design. Amsterdam: Pepin Press.

Wasino \& Hartatik, Endah Sri. (2018). Metode Penelitian Sejarah: dari Riset hingga Penulisan. Yogyakarta: Magnum Pustaka Utama.
Gorga : Jurnal Seni Rupa

Volume 10 Nomor 01 Januari-Juni 2021

p-ISSN: 2301-5942 | e-ISSN: 2580-2380

Wibowo, Januar, Haryanto Tanuwijaya, Achmad Yanu A.F. (2016). "Rancang Bangun Management Information System Batik Tradisional Jawa Timur sebagai Upaya Pelestarian Warisan Budaya Bangsa". Laporan Akhir Penelitian Hibah Bersaing. Tidak Diterbitkan. Surabaya: Institut Bisnis dan Informatika, STIKOM.

Wirawan, Rizky S. \& Trilaksana, Agus. (2015). Sejarah Industrialisasi Batik di Kampung Batik Jetis Sidoarjo Tahun 1970-2013. AVATARA, eJournal Pendidikan Sejarah, 3(3), 480-486.

Wulandari, Ari. (2011). Batik Nusantara; Makna Filosofis, Cara Pembuatan dan Industri Batik. Yogyakarta: Andi.

Wulandari, S.E., Imam As'ary, Yudi Prasetyo. (2013). Perkembangan Motif Batik Jetis Sidoarjo dalam Tinjauan Sejarah. GENTA: Jurnal Pendidikan Sejarah, 1(1), 1-12.

Yanuar. (2016, Oktober 19). Kampung Kuno Jetis Penghasil Batik Tulis Khas Sidoarjo. https://kabarinews.com/kampung-kuno-jetispenghasil-batik-tulis-khas-sidoarjo/87296 (diakses tanggal 17 April 2021). 